\title{
Changes and influencing factors of the sediment load in the Xiliugou basin of the upper Yellow River, China
}

\author{
Haifang Yao ${ }^{\mathrm{a}, \mathrm{b}}$, Changxing Shi ${ }^{\mathrm{a}, *}$, Wenwei Shao ${ }^{\mathrm{a}, \mathrm{b}}$, Jianbin Bai ${ }^{\mathrm{a}, \mathrm{b}}$, Hui Yang ${ }^{\mathrm{a}, \mathrm{b}}$ \\ ${ }^{a}$ Key Laboratory of Water Cycle and Related Land Surface Processes, Institute of Geographic Sciences and Natural Resources Research, Chinese Academy of Science, Beijing 100101, China \\ b University of Chinese Academy of Sciences, Beijing 100049, China
}

\section{A R T I C L E I N F O}

\section{Article history:}

Received 3 August 2015

Received in revised form 26 January 2016

Accepted 8 February 2016

Available online 20 February 2016

\section{Keywords:}

Sediment yield

Hyperconcentrated flow

RUSLE

Water and soil conservation

\begin{abstract}
A B S T R A C T
Based on the MK test and RUSLE model, changes in the soil erosion and sediment yield of the Xiliugou basin in the upper Yellow River during the period 1960-2013 were studied. The results indicate that hyperconcentrated floods are very typical in the Xiliugou basin. Hyperconcentrated floods occurred in $87.1 \%$ of the years during the period 1960-1990. Since the 2000s, the number of such floods was reduced considerably with the application of soil and water conservation, and only one hyperconcentrated flood was recorded from 2006 to 2013. Hyperconcentrated flows transfer most of the sediment yield in the Xiliugou basin. The sediment load carried by hyperconcentrated floods accounted for $84.7 \%$ of the total sediment yield in that basin during the period 1964-1990. Because hyperconcentrated flows may cause high and intensive erosion, the sediment eroded in gullies may be the main sediment source in the basin. Our results show that the percentages of gully erosion and slope erosion in this basin in the period $1964-1990$ were $76.1 \%$ and $23.9 \%$, respectively. A daily rainfall larger than $12 \mathrm{~mm}$ can cause hyperconcentrated flows, and the frequency of hyperconcentrated floods increases with the rainfall intensity. As a result of vegetation recovery and check-dam building, the frequency of hyperconcentrated flows and the annual sediment concentration and sediment yield for the same intensity of rainstorms were noticeably lower from 2006 to 2013 than those from 1964 to 1990 . From 1960 to 2013, the annual sediment yield of the basin showed a significant downward trend, whereas no significant trend was detected in the annual precipitation. The annual sediment yield and precipitation from 1999 to 2013 decreased by $82.1 \%$ and $1.7 \%$, respectively, compared with those in the period 1960-1998. The implementation of water and soil conservation measures and the reduced frequency of hyperconcentrated floods were the main reasons for the significant reduction in sediment yield in the period 2006-2013.
\end{abstract}

(C) 2016 Elsevier B.V. All rights reserved.

\section{Introduction}

Understanding long-term suspended sediment discharge changes and its influencing factors in watersheds is crucial for studying soil degradation, water quality, biogeochemical cycles and agricultural sustainability (Walling and Fang, 2003; Walling, 2006; Syvitski and Milliman, 2007; Walling, 2009; Pelletier, 2012; Vanmaercke et al., 2014). In recent decades, the sediment loads of many rivers throughout the world have experienced significant changes owing to climate change and human activities. Walling and Fang (2003) studied the trends of 146 major rivers in the world, and found that approximately half of them were in decline. The main reasons for this phenomenon were human activity, including reservoir construction, sediment control programs and soil and water conservation. Syvitski et al. (2005) provided global estimates of the seasonal flux of sediment under modern and prehuman conditions. They concluded that the reduction in the sediment flux was due to retention within reservoirs. The changes in runoff and sediment

\footnotetext{
* Corresponding author.

E-mail address: shicx@igsnrr.ac.cn (C. Shi).
}

load in the Upper Blue Nile basin were analyzed by Gebremicael et al. (2013) with the SWAT model, and the results indicated that land use/ cover change played an important role in the increases in annual runoff and sediment load. In China, Wu et al. (2012) studied the variation of the sediment load in the Zhujiang basin and addressed the causative role that dam construction and soil and water conservation have played in significantly decreasing sediment discharge. The sediment load in the Liaohe, Haihe, Yellow, Huaihe, Yangtze, Minjiang and Zhujiang rivers showed declining trends because of the effects of climate change and human activity (Liu et al., 2013), but the trend was not observed in the Songhua and Lancang rivers.

As the second longest river in China, the Yellow River is noted for its relatively low water discharge when compared with its huge sediment load. Since the 1970s, the water discharge and sediment load of the Yellow River have changed significantly, and many studies have been devoted to the analysis of the causes for the changes in the runoff and sediment load of the river. The studies by Shi et al. (2013) and Zhao et al. (2014) suggested that the decrease in the runoff in the middle Yellow River basin in recent decades was mainly due to human activity. The significant reduction of the sediment load of the Yellow River in 
recent decades was associated with climate change and human activity (including soil and water conservation, dam construction and vegetation restoration) (Miao et al., 2010; Gao et al., 2011; Xin et al., 2012; Mu et al., 2012; Xin et al., 2015). In their study, Gao et al. (2011) attributed $12.2 \%$ of the decrease in the sediment load of the middle Yellow River to precipitation and the remaining $87.8 \%$ to human activity. Another study by Xin et al. (2015) stated that human activity explained $83.6 \%$ of the total reduction in the sediment yield of the middle Yellow River from 2000-2010 and that soil and water conservation explained approximately $42.4 \%$ of the decrease in the sediment yield.

Ten small tributaries, including the Maobula, Buersetaigou, Heilaigou, Xiliugou, Hantaichuan, Haoqinghe, Hashilachuan, Muhaerhe, Dongliugou and Husitaihe, are principal sediment sources in the upper Yellow River and are adjacent to the middle Yellow River basin, which is one of the regions with the most severe soil erosion in the world. These tributaries originate from the Ordos Plateau, flow through the Hobq Desert and finally enter the Yellow River (Zhang et al., 2015). The upstream watersheds of the tributaries are in the loess hilly and gully region, their midstream watersheds are in a desert area, and their downstream reaches flow in an alluvial plain. Given the special geographical location and the natural environment, the ten small tributaries belong to regions where wind-water two-phase coupling processes prevail. Rainstorms can give rise to hyperconcentrated flows easily in the region, and the flows often destroy railways, village and factories downstream (Zhang et al., 2015; Du et al., 2014). Moreover, flash floods in the ten tributaries have carried high sediment loads into the Yellow River, leading to heavy sedimentation in the Inner-Mongolia reach of the upper Yellow River (Liu et al., 2009; Qin et al., 2011; Xu, 2013; Du et al., 2014). To date, some researchers have examined the characteristics of runoff and sediment load in this region. Wang et al. (2013) determined the characteristics of the hyperconcentrated flows. Ma et al. (2013) identified the dynamic processes of aeolian-fluvial interaction erosion. Xu $(2013,2014)$ investigated the erosion and sediment yield in relation to coupled wind-water processes and hyperconcentrated flows and their temporal and spatial variations. Nevertheless, there have been few studies regarding changes in erosion and the sediment yield and their influencing factors in the ten small tributaries. The hydrological and sediment records in this region are limited. There are only three hydrological stations on three of the tributaries, but the hydrological and sediment records at the gauging station in the Xiliugou basin are relatively long and complete. Hence, we selected one of the ten small tributaries, the Xiliugou basin, as a case to study the characteristics and causes of variations in the sediment loads of the ten small tributaries.

The objectives of this paper are as follows: (1) to analyze the variation tendency of the sediment yield in the Xiliugou basin using hydrological and sediment records from 1960 to 2013 and (2) to identify the factors that have affected the sediment load of the tributary. A better understanding of the long-term suspended sediment discharge changes and the influencing factors might provide a theoretical basis for improving policy and plans for water and soil conservation in this sediment source area of the upper Yellow River and also serve as a reference for studying the same issues in other rivers.

\section{Study area and data}

\subsection{Study area}

The Xiliugou basin is located between $109^{\circ} 24^{\prime}-110^{\circ} 00^{\prime} \mathrm{E}$ and $39^{\circ} 47^{\prime}-40^{\circ} 30^{\prime} \mathrm{N}$ and lies in the middle of the ten small tributaries (Fig. 1). It has a drainage area of $1180 \mathrm{~km}^{2}$ and falls from 1551 to $1029 \mathrm{~m}$. The watershed is in a semi-arid climate zone. It has a long and cold winter and a short and torrid summer. From November to April, it is windy. The mean annual temperature was $6.8^{\circ} \mathrm{C}$, and the average annual precipitation was $289.4 \mathrm{~mm}$ in the period 1960 to 2013. The distribution of monthly precipitation, runoff, and sediment load is extremely uneven and is mainly concentrated in the flood season (from June to September). Precipitation in the flood season accounted for $79.8 \%$ of the total annual precipitation, producing $55.7 \%$ of the yearly runoff that carried $87 \%$ of the yearly sediment load.

\subsection{Data collection}

The data used in this paper include annual runoff and sediment load (1960-2013), maximum sediment concentration from 1960-2013 (excluding the period 1991-2005), daily discharge and sediment concentration from 1964-2013 (excluding the period 1991-2005), geometric measurements of the channel cross section at the Longtouguai hydrological station in the Xiliugou basin from 2006-2013 and daily meteorological data at 14 rainfall stations and 10 weather stations from 1960-2013. The runoff, sediment and geometric measurements of the channel cross section at the Longtouguai hydrological station and the precipitation data at the 14 rainfall stations were collected from the Yellow River Conservancy Commission (YRCC). The meteorological data at the 10 weather stations were provided by the National Climate Centre (NCC) of China Meteorological Administration (CMA). Using the IDW tool in ArcGIS, the mean daily rainfall of the Xiliugou basin was extracted from the daily records at the rainfall and weather stations.

Landsat-5 Thematic Mapper (TM) images (1989, 2011) were chosen to develop a land use map and the Normalized Difference Vegetation Index (NDVI) using ENVI and ArcGIS software. After geometric and atmospheric correction processing, we used human-computer interactive interpretation technology to develop the land use map. To improve the classification accuracy, the land use was classified into five types: farmland, forest and grass land, construction land, water area and unused land (vegetation coverage $<5 \%$, including bare land, desert and saline land). A soil database at a scale of 1:1,000,000 was provided by the Data Center for Resources and Environmental Sciences, Chinese Academy of Sciences (RESDC) (http://www.resdc.cn), and the TM images with a resolution of 30-m and DEM with a resolution of $90 \mathrm{~m}$ were downloaded from the Geospatial Data Cloud website (http://www. gscloud.cn/). All of the spatial data were converted into a raster format with a $100-\mathrm{m}$ resolution.

\section{Methods}

\subsection{Trend analysis}

The Mann-Kendall (MK) test (Mann, 1945; Kendall, 1975) is a popular non-parametric method for analyzing trends in hydrologic variables (Rougé et al., 2013; Ahn and Merwade, 2014). For a given time series $X\left(x_{1}, x_{2}, \ldots, x_{n}\right)$, the statistics $S$ is defined as

$S=\sum_{i=1}^{n-1} \sum_{j=i+1}^{n} \operatorname{sgn}\left(x_{j}-x_{i}\right)$,

where

$\operatorname{sgn}\left(x_{j}-x_{i}\right)=\left\{\begin{array}{cc}1 & x_{j}>x_{i} \\ 0 & x_{j}=x_{i} \\ -1 & x_{j}<x_{i}\end{array}\right.$

$n$ is the sample size. If $n$ is greater than 8 , the $S$ values will follow an approximately normal distribution (Zhang et al., 2011). Its variance is calculated as

$\operatorname{Var}(S)=\frac{n(n-1)(2 n+S)}{18}$ 


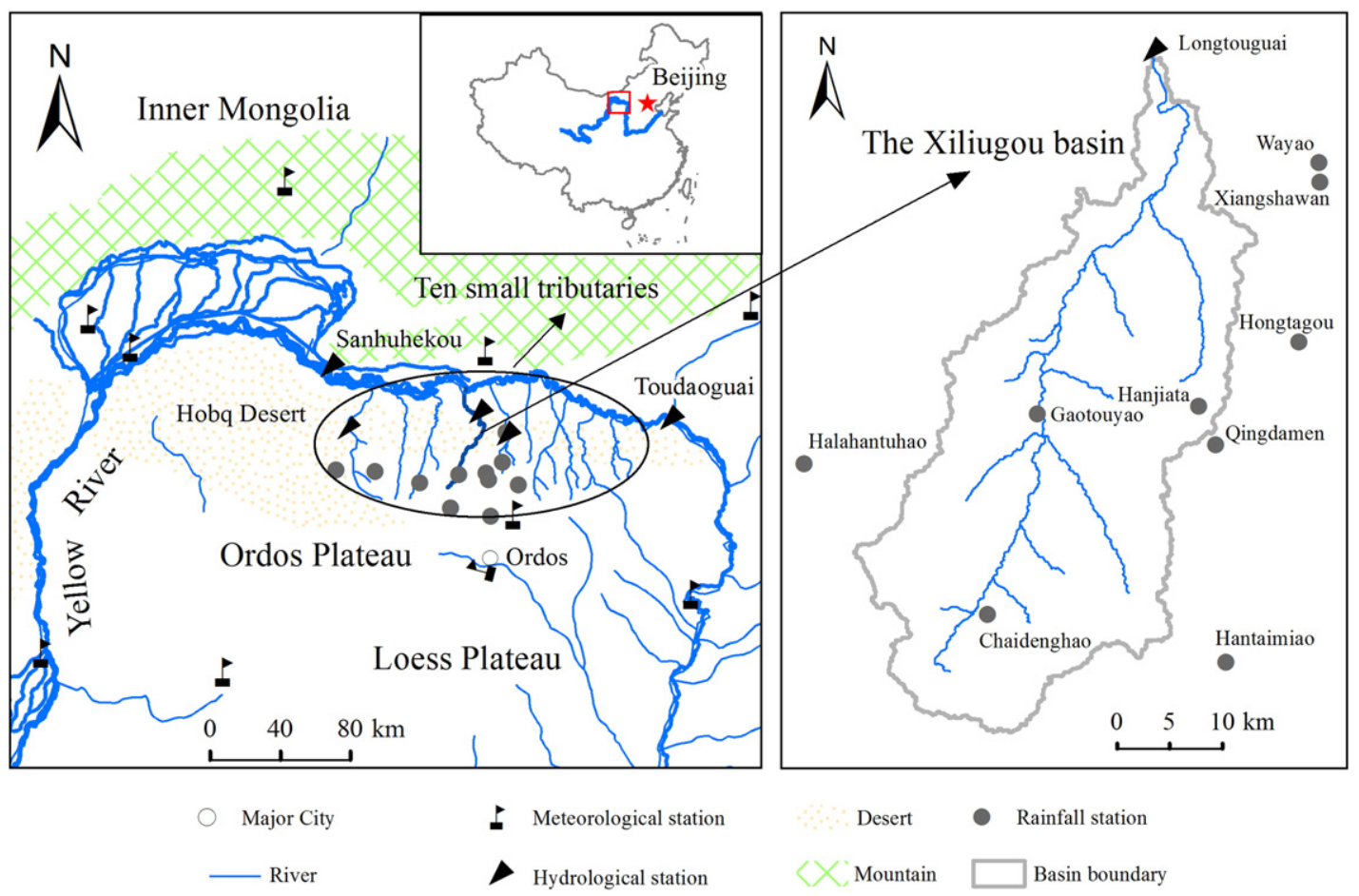

Fig. 1. Location of the Xiliugou basin.

Then, the Mann-Kendall $Z$ is given by

$Z=\left\{\begin{array}{cc}(S-1) / \sqrt{\operatorname{Var}(S)} & S>0 \\ 0 & S=0 \\ (S+1) / \sqrt{\operatorname{Var}(S)} & S<0\end{array}\right.$

A positive value of $Z$ indicates an increasing trend, and vice versa. The null hypothesis of no trend is rejected if $|Z|>1.96$ at the $5 \%$ significance level.

\subsection{Breakpoint detection}

The Pettitt test (Pettitt, 1979) is a non-parametric method that is widely applied to detect abrupt changes in water discharge and sediment load (Fan et al., 2012; Rougé et al., 2013). For a given time series $X\left(x_{1}, x_{2}, \ldots, x_{N}\right)$, which is divided into two samples $x_{1}, x_{2}, \ldots, x_{t}$ and $x_{t+1}, x_{t+2}, \ldots, x_{N}$, the Pettitt test uses a version of the MannWhitney statistics $U_{t, N}$ calculated as

$U_{t, N}=U_{t-1, N}+\sum_{j=1}^{N} \operatorname{sgn}\left(x_{t}-x_{j}\right), \quad t=2,3, \ldots, N$

where

$\operatorname{sgn}\left(x_{t}-x_{j}\right)=\left\{\begin{array}{cc}1 & x_{t}>x_{j} \\ 0 & x_{t}=x_{j} \\ -1 & x_{t}<x_{j}\end{array}\right.$

The breakpoint is defined to be where $\left|U_{t, N}\right|$ reaches its maximum value:

$K_{t, N}=\operatorname{Max}\left|U_{t, N}\right|, \quad(1 \leq t \leq N)$.
The significance level associated with $K_{t, N}$ is determined approximately by

$p \cong 2 \exp \left[-6\left(K_{t, N}\right)^{2} /\left(N^{3}+N^{2}\right)\right]$.

If $p<0.05$, a significant change point exists.

\subsection{RUSLE model}

The Universal Soil Loss Equation (USLE) model is a widely used method to assess slope erosion (Cai et al., 1996), and its revised version is called the Revised Universal Soil Loss Equation (RUSLE) model. In this paper, we used the RUSLE (Renard et al., 1997) model to estimate soil loss in the Xiliugou basin during the period 1964-2013. The RUSLE model equation is defined as

$A=R \times K \times L S \times C \times P$

where $A$ is the average soil loss $\left(\mathrm{t} \mathrm{ha}^{-1} \mathrm{yr}^{-1}\right) ; R$ is the rainfall erosivity factor (MJ mm ha $\left.{ }^{-1} \mathrm{~h}^{-1} \mathrm{yr}^{-1}\right) ; K$ is the soil erodibility factor ( $\mathrm{t}$ ha $\mathrm{h} \mathrm{ha}^{-1} \mathrm{MJ}^{-1} \mathrm{~mm}^{-1}$ ); $L S$ is the slope length-steepness factor (dimensionless); $C$ is the vegetation cover factor (dimensionless); and $P$ is the erosion control practice factor (dimensionless).

\subsubsection{Rainfall erosivity factor $(R)$}

Rainfall erosivity is very important among the natural factors that affect soil erosion (Angulo-Martínez and Beguería, 2009). It is one of the key drivers that determine the dynamics of runoff loss and sediment yield in the semi-arid Chinese Loess Plateau (Wei et al., 2015). Based on the daily rainfall data, the annual rainfall erosivity was calculated using Eqs. (10)-(12), which have been widely used in China (Zhang et al., 2002):

$$
M_{i}=\alpha \sum_{j=1}^{k}\left(D_{j}\right)^{\beta}\left\{\begin{array}{cc}
D_{j}=D_{j} & D_{j}>12 \mathrm{~mm} \\
D_{j}=0 & D_{j} \leq 12 \mathrm{~mm}
\end{array}\right.
$$


and

$\beta=0.8363+\frac{18.177}{\bar{p}_{d 12}}+\frac{24.455}{\bar{p}_{y 12}}$

$\alpha=21.586 \beta^{-7.1891}$

where $M_{i}$ is the half-month rainfall erosivity ( $\left.\mathrm{MJ} \mathrm{mm} \mathrm{ha} \mathrm{m}^{-1} \mathrm{~h}^{-1} \mathrm{yr}^{-1}\right) ; i$ ranges from 1 to $24 ; k$ is the number of days in the half-month; and $D_{j}$ is the effective rainfall on the $j$ th day. $\bar{p}_{d 12}$ and $\bar{p}_{y 12}$ are the average daily rainfall and yearly average rainfall for days with rainfall greater than $12 \mathrm{~mm}$, respectively. Then, the annual rainfall erosivity $(R)$ can be expressed by the summation of the $M_{i}$.

\subsubsection{Soil erodibility factor $(K)$}

The EPIC (Williams et al., 1984) equation (Eq. (13)) is widely used to determine the soil erodibility factor (Sun et al., 2014; Xiao et al., 2015). The physical properties of the soil (such as texture, thickness and organic matter content) were acquired from China's second soil survey data. Followed the EPIC method, the $K$ factor in the Xiliugou basin was obtained and assigned to the soil map:

$$
\begin{aligned}
K= & \left\{0.2+0.3 \exp \left[-0.0256 \operatorname{SAN}\left(1-\frac{S I L}{100}\right)\right]\right\} \times\left(\frac{S I L}{C L A+S I L}\right)^{0.3} \\
& \times\left[1-\frac{0.25 C}{C+\exp (3.72-2.95 C)}\right] \times\left[1-\frac{0.7 S N I}{S N I+\exp (-5.51+22.9 S N I)}\right]
\end{aligned}
$$

where SAN, SIL and CLA are the sand fraction (\%), silt fraction (\%) and clay fraction (\%), respectively; $C$ is the soil organic carbon content (\%); and $S N I=1-S A N / 100$.

\subsubsection{Topographic factor ( $L S)$}

According to the methods developed by McCool et al. (1997) and Liu et al. (1994), the slope length factor $(L)$ and the steepness factor $(S)$ were estimated based on the DEM and the ArcGIS software:

$L=\left(\frac{\gamma}{22.13}\right)^{m}\left\{\begin{array}{cc}m=0.5 & \theta \geq 9 \% \\ m=0.4 & 9 \%>\theta \geq 3 \% \\ m=0.3 & 3 \%>\theta \geq 1 \%\end{array}\right.$

and

$S=\left\{\begin{array}{cc}10.8 \sin \theta+0.03 & \theta<9 \% \\ 16.8 \sin \theta-0.5 & 9 \% \leq \theta \leq 18 \% \\ 21.91 \sin \theta-0.96 & \theta>18 \%\end{array}\right.$

where $\gamma$ is the horizontal slope length; $\theta$ is the slope derived from the DEM; and $m$ is the dimensionless constant that depends on $\theta$.

\subsubsection{Vegetation cover factor (C)}

Soil loss is significantly related to land cover. When the land use is altered, the landscape and vegetation cover are shifted; consequently, the relation of rainfall-runoff-soil erosion is changed (Wei et al., 2015). NDVI well represents vegetation cover and is usually used to estimate the $C$ factor. Cai et al. (2000) developed a method to estimate the $C$ factor using NDVI. The formula is

$C=\left\{\begin{array}{cc}1 & f=0 \\ 0.6508-0.3436 \lg f & 0<f \leq 78.3 \% \\ 0 & f>78.3 \%\end{array}\right.$

and

$f=\left(N D V I-N D V I_{\text {soil }}\right) /\left(N D V I_{\text {veg }}-N D V I_{\text {soil }}\right)$

where $f$ is the vegetation coverage, $N D V I_{\text {soil }}$ is the $N D V I$ value for pure bare soil pixels, and $N D V I_{v e g}$ is the NDVI value for pure vegetation pixels.

\subsubsection{Erosion control practice factor $(P)$}

Referring to the research results of Yang (2012) and Sun et al. (2014), the $P$ values of the farmland, forest and grass land, water area, construction land and unused land were set to $0.55,0.8,1,1$ and 1 , respectively. The $P$ value of the deserts was set to 0 considering that precipitation almost seeps completely in desert areas.

\section{Results}

\subsection{Characteristics of varying annual and inter-annual sediment load}

Fig. 2 shows that the annual sediment load changed obviously during the period 1960-2013 in the Xiliugou basin. It fluctuated widely in a range of $0.01 \times 10^{4}-4749 \times 10^{4} \mathrm{t} / \mathrm{a}$, with an average of $420.1 \times 10^{4} \mathrm{t} / \mathrm{a}$ and a coefficient of variation $\left(C_{v}\right)$ as high as 1.9. Regarding the annual sediment discharge of $614.9 \times 10^{4}$ t/a during 1960-1969 as the reference value, except during the $1980 \mathrm{~s}\left(673.5 \times 10^{4} \mathrm{t} / \mathrm{a}\right)$, the sediment discharge during the $1970 \mathrm{~s}\left(438.3 \times 10^{4} \mathrm{t} / \mathrm{a}\right)$, the $1990 \mathrm{~s}\left(409.6 \times 10^{4} \mathrm{t} / \mathrm{a}\right)$ and from $2000-2013\left(94.3 \times 10^{4} \mathrm{t} / \mathrm{a}\right)$ decreased by $28.7 \%, 33.4 \%$ and $84.6 \%$, respectively.

Moreover, the intra-annual distribution of the sediment load was quite uneven. The sediment load transported in the flood season accounted for $87.7 \%$ of the total sediment load in the basin during the period 1964-2013, and the majority of the sediment load was transported by one or several flood events. For example, the flood event on 21/7/1989 transported $99.9 \%$ of the total river load.

The MK test was employed to estimate trends in the annual sediment load and precipitation (Figs. 2,3). The results indicate that the annual sediment load decreased significantly at the $99 \%$ confidence level, with a $Z$ value of -2.82 . For the precipitation series, no significant trend was detected.

Using the Pettitt test, we examined the abrupt changes in the annual sediment load series that were recorded at the Longtouguai hydrological station from 1960-2013. Fig. 4 shows the changes in the $U_{t, N}$ statistics of the Pettitt test during the period 1960-2013. Obviously, an abrupt change appeared in 1998 and was statistically significant, with a $p$ value of 0.003 . According to the breakpoint, the study period was divided into a nature period (1960-1998) and an impact period (19992013). In the nature period, the mean annual precipitation and sediment load were $290.8 \mathrm{~mm}$ and $544.2 \times 10^{4} \mathrm{t} / \mathrm{a}$, respectively, whereas in the impact period they were $285.8 \mathrm{~mm}$ and $97.3 \times 10^{4} \mathrm{t} / \mathrm{a}$, respectively. In contrast with the nature period, the mean annual precipitation and sediment load in the impact period decreased by $1.7 \%$ and $82.1 \%$, respectively.

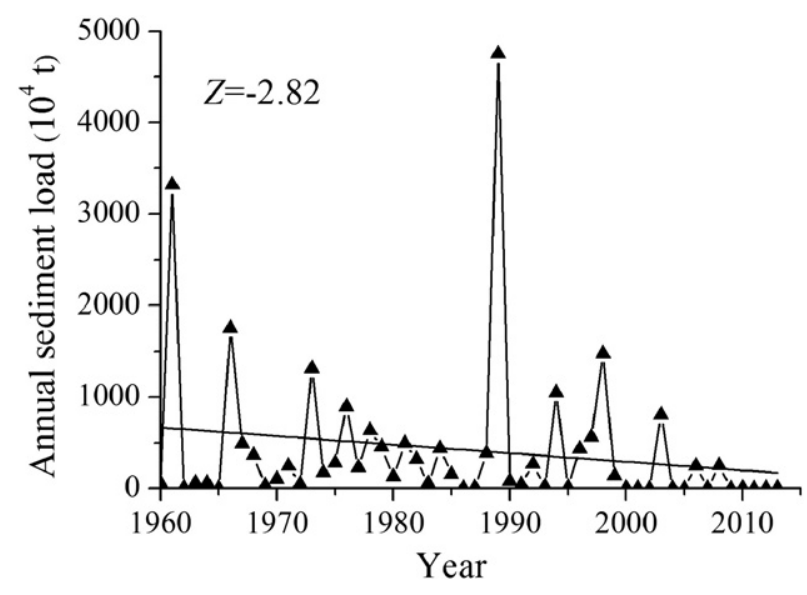

Fig. 2. Trend of annual sediment load $(|Z| \geq 1.96, p<0.05 ;|Z| \geq 2.576, p<0.01)$. 


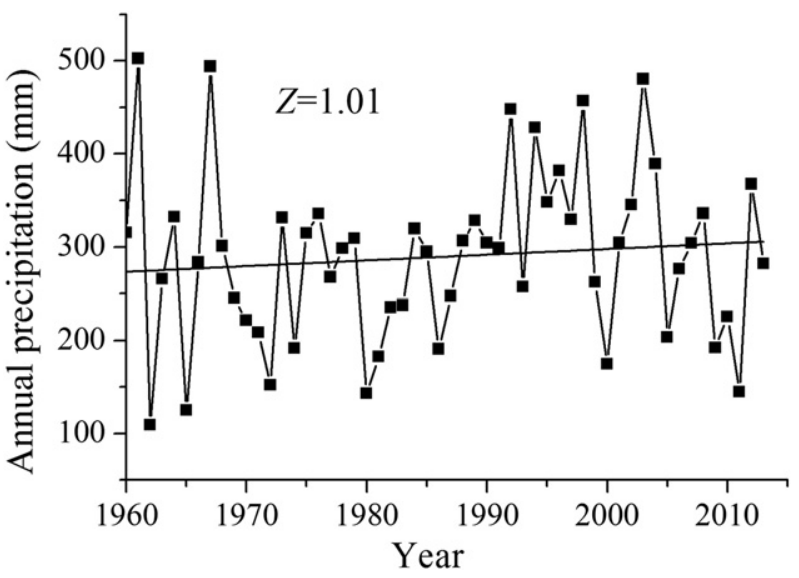

Fig. 3. Trend of annual precipitation $(|Z| \geq 1.96, p<0.05 ;|Z| \geq 2.576, p<0.01)$.

4.2. Changes in the hyperconcentrated flow and its impacts on the sediment load

In the region of the ten small tributaries, hyperconcentrated floods are typical because of the specific natural conditions and geographic location. The hyperconcentrated floods are characterized by a high peak, large flood volume, high sediment concentration and a sharp rise and fall (Wang et al., 2013). According to measurements made over ten years in a catchment on the Loess Plateau, the hyperconcentrated flows form on the lower hillslopes and develop well in the gullies $\mathrm{Xu}$, 2004). The suspended sediment concentration is commonly used as an index for defining the hyperconcentrated flows. However, there is not a consistent standard for the suspended sediment concentration for hyperconcentrated flows (Xu, 2004). Xu (2013) adopts an annual maximum sediment concentration of $300 \mathrm{~kg} / \mathrm{m}^{3}$ for hyperconcentrated flows in the Xiliugou basin. Wang et al. (2013) plotted the relationship between the suspended concentration and the flow strength index (Fig. 5). The result shows that a sediment concentration of approximately $300 \mathrm{~kg} / \mathrm{m}^{3}$ requires the largest flow strength, and the flow strength index declines for a higher sediment concentration. Hyperconcentrated flows play a dominant role in channel-forming processes on the Loess Plateau (Wan and Shen, 1978; Xu, 1999). Thus, in this study, flows with a maximum sediment concentration greater than $300 \mathrm{~kg} / \mathrm{m}^{3}$ are also considered to be hyperconcentrated flows. Based on the observed suspended sediment concentration at the Longtouguai station, the temporal variation in the annual maximum sediment concentration is plotted in Fig. 6. It can be observed that

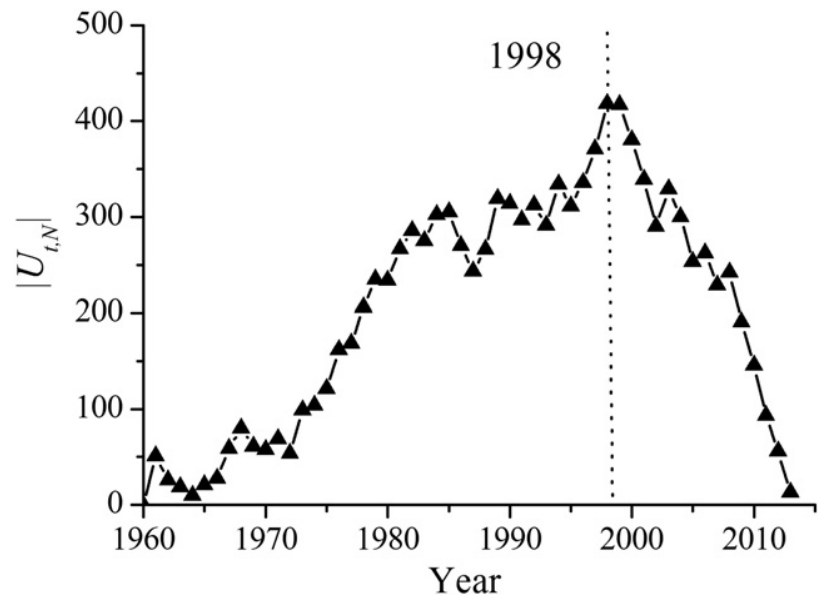

Fig. 4. Abrupt change in the annual sediment load during the period 1960-2013.

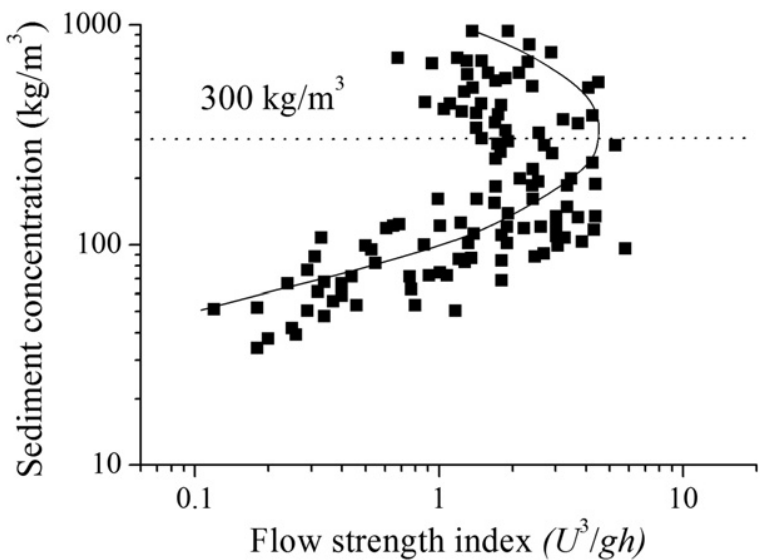

Fig. 5. Relationship between the flow strength index $\left(U^{3} / g h\right)$ and sediment concentration. After Wang et al. (2013).

hyperconcentrated floods are very common in the Xiliugou basin. Hyperconcentrated floods occurred in 27 years during the period $1960-1990$, which is a frequency of $87.1 \%$. Among those floods, the annual maximum sediment concentration in many years was greater than $1000 \mathrm{~kg} / \mathrm{m}^{3}$. Since the 2000s, it has dropped considerably, and only one hyperconcentrated flood, which had a sediment concentration of $487 \mathrm{~kg} / \mathrm{m}^{3}$, was recorded from 2006 to 2013 .

Considering the averaging effect of daily means on extreme sediment concentration, we designated flows with daily suspended sediment concentrations equal to or greater than $200 \mathrm{~kg} / \mathrm{m}^{3}$ as hyperconcentrated flows. To demonstrate the influence of hyperconcentrated flows on the sediment yield, we plotted the ratio of sediment yield transported by hyperconcentrated floods in each year from 1964 to 2013 (Fig. 7). It can be observed that the sediment yield transported by hyperconcentrated floods accounted for $84.7 \%$ of the total sediment load in this basin during the period 1964-1990. Except for a few years, the proportion of the sediment yield that was transported by the hyperconcentrated flows in each year was greater than $50 \%$ and at times exceeded 99\%. For instance, in 1966, hyperconcentrated flows only occurred twice but carried $99.2 \%$ of the yearly sediment load. Another example is the hyperconcentrated flood event of $21 / 7 / 1989$. The peak discharge was $6940 \mathrm{~m}^{3} / \mathrm{s}$, and the sediment concentration was as high as $1240 \mathrm{~kg} / \mathrm{m}^{3}$. This large flood transported almost all (99.9\%) of the total load in 1989. In contrast to the period 1960-1990, hyperconcentrated flows occurred only once from 2006-2013, but that event still transported $37.2 \%$ of the total sediment load for the entire period. Thus, hyperconcentrated flows were responsible for the high sediment yield in the Xiliugou basin before 1990 and made a

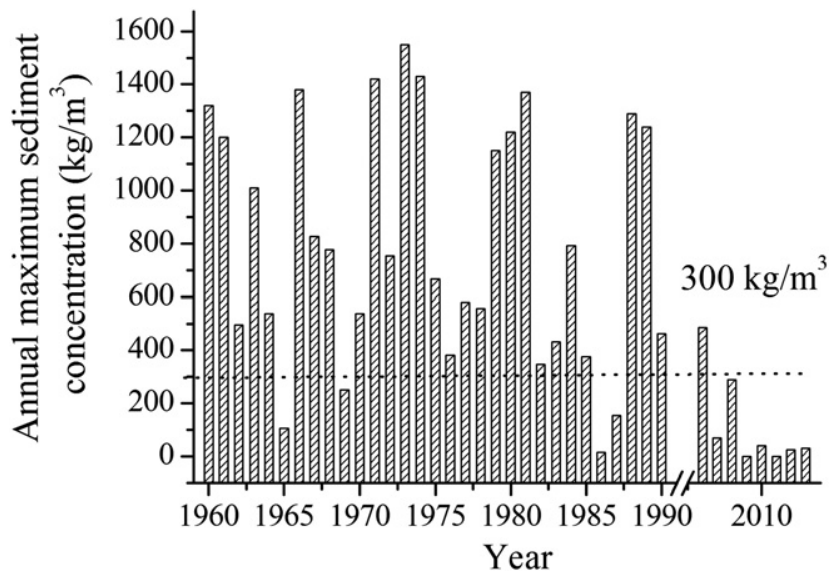

Fig. 6. Temporal variation in the annual maximum sediment concentration. 


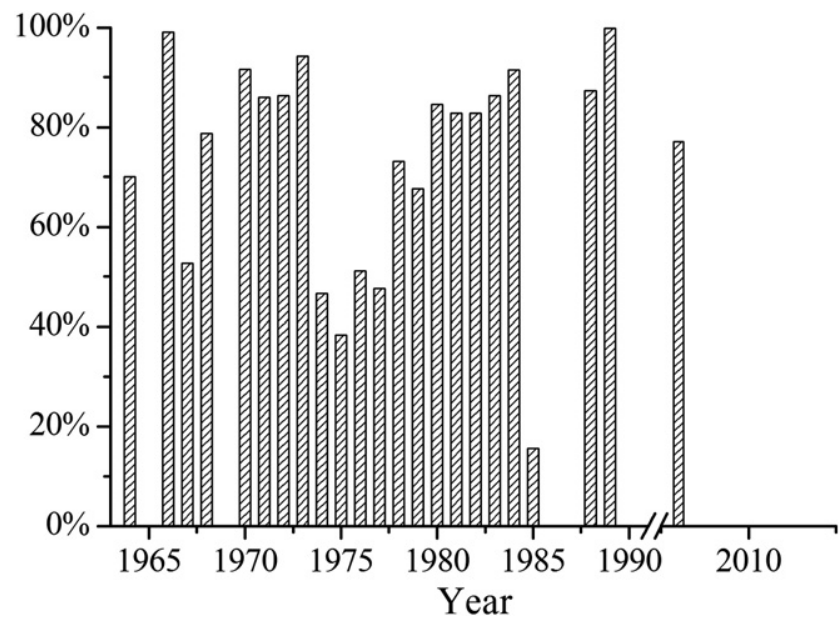

Fig. 7. The percentage of sediment yield transported by hyperconcentrated flows.

considerable contribution to the sediment output of the basin from 2006-2013.

\subsection{Estimating soil loss using the RUSLE model}

The annual average soil erosion rates for the periods 1964-1990 and 2006-2013 in the Xiliugou basin were estimated using the RUSLE model (Figs. 8, 9). The results show that the spatial distributions of the average soil erosion during those two periods were nearly the same. The highest soil erosion rates were mainly located in the hilly and gully areas, where the slopes are relatively high with a loess-covered incompact Cretaceous sandstone substrate that is vulnerable to erosion. Although most

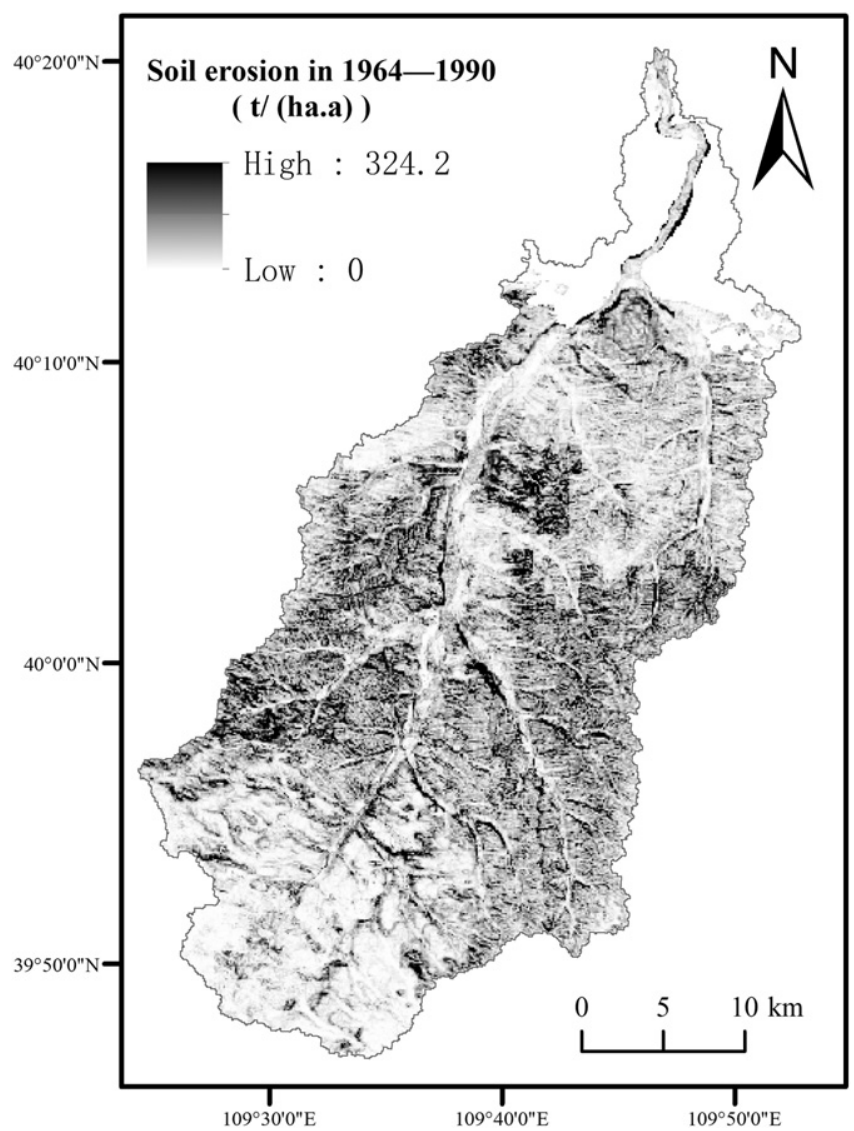

Fig. 8. The distribution of the annual average soil erosion in the period 1964-1990.

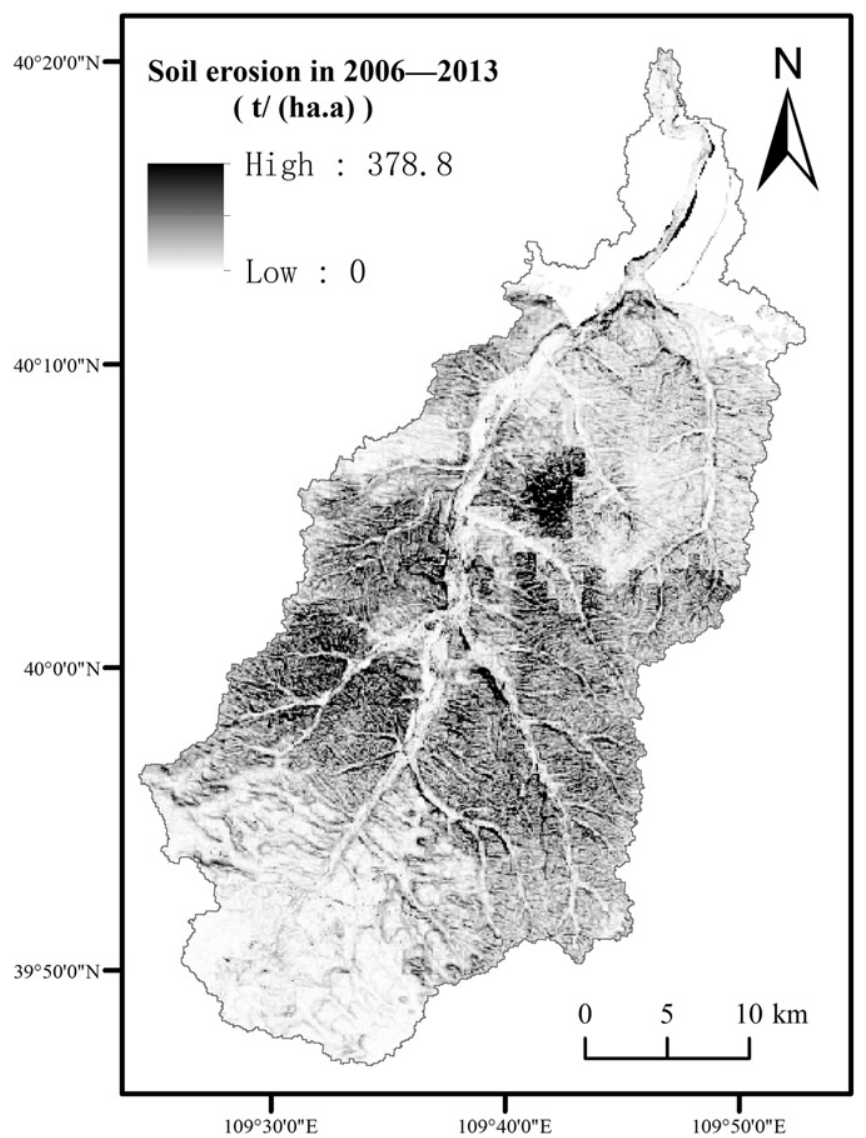

Fig. 9. The distribution of the annual average soil erosion in the period 2006-2013.

of the farmland is distributed in the southern part of the basin, the soil erosion rates in the southern part were lower because the slopes there are less than $5^{\circ}$. The desert in the northern part of this basin has an excessive infiltration rate, so the soil erosion rates there are the lowest. During 1964-1990, the annual volume of soil erosion was $123.5 \times 10^{4} \mathrm{t} / \mathrm{a}$, whereas in 2006-2013, it was $98.0 \times 10^{4} \mathrm{t} / \mathrm{a}$. The soil erosion decreased by $20.6 \%$ from the former period to the later period.

\section{Discussion}

\subsection{Slope erosion vs. gully erosion}

In the Xiliugou basin, the annual average soil erosion estimated above by the RUSLE model in the periods 1964-1990 and 2006-2013 was $123.5 \times 10^{4} \mathrm{t} / \mathrm{a}$ and $98.0 \times 10^{4} \mathrm{t} / \mathrm{a}$, respectively. In contrast, the observed annual sediment load in those two periods was $514.9 \times 10^{4} \mathrm{t} / \mathrm{a}$ and $63.2 \times 10^{4} \mathrm{t} / \mathrm{a}$, respectively. Thus, the annual average soil erosion estimated by the RUSLE model was only $23.9 \%$ of that measured for the period $1964-1990$, whereas it was $155.1 \%$ of that measured for the period 2006-2013. This phenomenon can be attributed to the special natural conditions, geographic location and changing erosion environment of the Xiliugou basin. The Xiliugou basin is in a region where windwater two-phase coupling processes prevail, and hyperconcentrated flows are common. The hyperconcentrated flows occur as a result of erosion, but they also enhance soil erosion and accelerate gully erosion because they have very high erosion and transport abilities (Xu, 1999). Numerous researchers have reported that gully erosion plays an important role in sediment production (Wasson et al., 2002; Krause et al., 2003; Poesen et al., 2003; Valentin et al., 2005; De Vente et al., 2005). Poesen et al. (2003) found that the gully erosion was an important sediment source in a catchment and that the soil loss caused by gully erosion contributed from 10\%-94\% of the total sediment yield. Tang 
(1991) suggested that the sediment supplied by gully erosion in the Loess Plateau was responsible for $53.6 \%-93.2 \%$ of the total soil erosion, whereas that by sheet and rill erosion only accounted for $6.8 \%-46.4 \%$. As noted earlier, from 1964-1990, the frequency of hyperconcentrated flows was higher, and these flows transported $84.7 \%$ of the total sediment load in the Xiliugou basin. Hyperconcentrated flows were the main reason for the serious soil erosion in the basin during the period 1964-1990. However, the soil erosion that is calculated by the RUSLE model is sheet and rill erosion. It does not consider the serious gully erosion caused by hyperconcentrated flows. Therefore, the erosion estimated by the RUSLE model could be regarded as the slope erosion, which was responsible for $23.9 \%$ of the total sediment yield in 1964-1990, and the other $76.1 \%$ should be attributed to gully erosion, which is commonly associated with hyperconcentrated flows. These results are consistent with those given in Poesen et al. (2003) and Tang (1991). In 2006-2013, the frequency of hyperconcentrated flows declined significantly. The reduction of hyperconcentrated flows resulted in the decrease in the observed annual sediment load. Moreover, with the reduction of hyperconcentrated flows, the main stem of the Xiliugou River might have become a sediment sink. As shown in Fig. 10, the river bed was raised by approximately $1.3 \mathrm{~m}$ at the Longtouguai station on the Xiliugou mainstem during 2006-2013, illustrating that a large amount of sediment was deposited in the river channel. Another cause of the sediment yield reduction was sediment detainment behind checkdams built in the gullies in the past decade, which will be explained below. Thus, the estimated slope erosion during 2006-2013 was 55.1\% higher than the observed sediment yield.

\subsection{Causes for the reduction in sediment yield}

5.2.1. The comparison of changes in rainfall with those in runoff and sediment yield

As shown in Table 1, the statistics of the observed annual runoff and sediment load in the periods 1964-1990 and 2006-2013 demonstrated that the annual runoff during the period 1964-1990 was $3017 \times 10^{4} \mathrm{~m}^{3}$ and decreased to $1430 \times 10^{4} \mathrm{~m}^{3}$ in the more recent years. The annual sediment load in 1964-1990 was $514.9 \times 10^{4} \mathrm{t} / \mathrm{a}$ and declined to $63.2 \times 10^{4} \mathrm{t} / \mathrm{a}$. Taking the first period (1964-1990) as the reference period, the runoff and sediment load in the second period (2006-2013) was reduced by $52.6 \%$ and $87.7 \%$, respectively. However, the marked reductions in both the runoff and sediment load could not be attributed to changes in precipitation because the annual precipitation did not have a significant decrease trend, and the percentage of the reduction was only $1.1 \%$ (Table 1 and Fig. 3). According to Eqs. (2)-(4), the annual average rainfall erosivity during the two periods was $802.9 \mathrm{MJ} \cdot \mathrm{mm} /(\mathrm{ha} \cdot \mathrm{h} \cdot \mathrm{a})$ and $771.4 \mathrm{MJ} \cdot \mathrm{mm} /(\mathrm{ha} \cdot \mathrm{h} \cdot \mathrm{a})$, respectively. In comparison with the reference period, the annual average

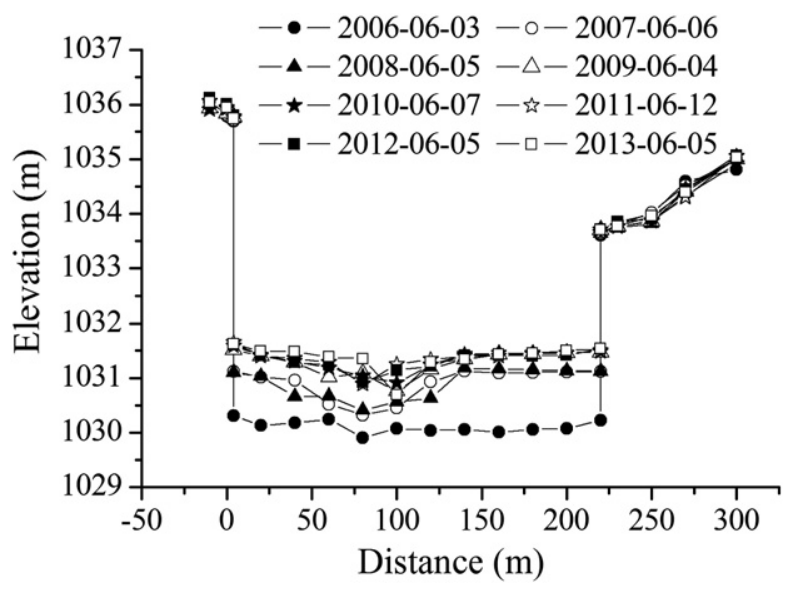

Fig. 10. Changes in the channel bed at the Longtouguai station from 2006-2013.
Table 1

Changes in the observed annual precipitation, runoff and sediment load of the Xiliugou basin in the periods 1964-1990 and 2006-2013.

\begin{tabular}{llll}
\hline Period & $\begin{array}{l}\text { Annual precipitation } \\
(\mathrm{mm})\end{array}$ & $\begin{array}{l}\text { Annual runoff } \\
\left(10^{4} \mathrm{~m}^{3}\right)\end{array}$ & $\begin{array}{l}\text { Annual sediment load } \\
\left(10^{4} \mathrm{t}\right)\end{array}$ \\
\hline $1964-1990$ & 266.7 & 3018 & 514.9 \\
2006-2013 & 263.7 & 1430 & 63.2 \\
Changes & $-3.0(-1.1 \%)$ & $-1588(-52.6 \%)$ & $-451.6(-87.7 \%)$ \\
\hline
\end{tabular}

rainfall erosivity decreased by 3.9\% in the second period. Lu et al. (2013) suggested that every $1 \%$ change in precipitation resulted in a $1.3 \%$ change in runoff and a $2 \%$ change in sediment loads. As given above, the annual precipitation decreased by $1.1 \%$, and the rainfall erosivity decreased by $3.9 \%$, whereas the annual runoff and the sediment load decreased by $52.6 \%$ and $87.7 \%$, respectively. These contrasts between changes in rainfall and runoff and between changes in rainfall erosivity and sediment yield indicate that human activity has played an important role in the reductions of both the runoff and sediment load in the Xiliugou basin.

\subsubsection{Impacts of soil and water conservation measures}

The Xiliugou basin is located in Dalate Banner (a county in Ordos city) on the Ordos Plateau. Since 1999, many soil and water conservation measures (such as planting forest and grass, building check-dams and enclosures) have been implemented in Dalate Banner (Liu et al., 2015). Subsequent to those soil and water conservation measures, the land use/cover was changed, and the vegetation cover was significantly improved. Table 2 shows the areas of land use/cover in the Xiliugou basin from 1989 to 2011. It is clear that the forest and grass land was the major land use type, followed by unused land, farmland, water areas and building land. From 1989 to 2011, building land and forest and grass land increased by $46.1 \%$ and $13.4 \%$, respectively, whereas unused land, water and farmland decreased by $41.4 \%, 7.1 \%$ and $3.6 \%$, respectively. The area change in unused land was the greatest, followed by the forest and grass land. In 1989, the unused land area was 24,079 ha and decreased to 14,091 ha in 2011. During the same period, the area of forest and grass land increased from 73,185 ha to 83,004 ha. Considering that water availability is the control element for vegetation growth in this semi-arid region, the vegetation restoration in the basin could be attributed principally to the implementation of conservation measures including afforestation, grass-planting and enclosure.

Vegetation restoration reduced slope erosion and runoff yield, and the reduction of runoff gave rise to the decrease of incision in gullies, so the frequency of hyperconcentrated flows declined. As revealed earlier, the hyperconcentrated flows carried most of the sediment yield in the Xiliugou basin, and the reduction in the hyperconcentrated flows was the dominant reason for the decrease in sediment load. Thus, the reduction in the hyperconcentrated flows from a frequency of $87.1 \%$ of the years in the period 1964-1990 to only one year in the period 2006-2013 should be the result of the implementation of soil and water conservation measures.

In addition to the vegetation restoration, engineering measures are another efficient way to reduce the frequency of hyperconcentrated

Table 2

Land use/cover change, 1989-2011.

\begin{tabular}{|c|c|c|c|c|c|c|}
\hline \multirow[b]{2}{*}{ Land use } & \multicolumn{2}{|l|}{1989} & \multicolumn{2}{|l|}{2011} & \multicolumn{2}{|l|}{ Changes } \\
\hline & $\begin{array}{l}\text { Area } \\
\text { (ha) }\end{array}$ & $\begin{array}{l}\text { Percentage } \\
\text { (\%) }\end{array}$ & $\begin{array}{l}\text { Area } \\
\text { (ha) }\end{array}$ & $\begin{array}{l}\text { Percentage } \\
(\%)\end{array}$ & $\begin{array}{l}\text { Area } \\
\text { (ha) }\end{array}$ & $\begin{array}{l}\text { Percentage } \\
(\%)\end{array}$ \\
\hline Farmland & 12,599 & 10.6 & 12,143 & 10.2 & -456 & -3.6 \\
\hline $\begin{array}{l}\text { Forest and } \\
\text { grass land }\end{array}$ & 73,185 & 61.9 & 83,004 & 70.3 & 9819 & 13.4 \\
\hline Water & 5922 & 5.0 & 5499 & 4.6 & -423 & -7.1 \\
\hline Building land & 2273 & 1.9 & 3321 & 2.8 & 1048 & 46.1 \\
\hline Unused Land & 24,079 & 20.4 & 14,091 & 11.9 & -9988 & -41.4 \\
\hline
\end{tabular}


flows. In 1997, there were only two large check-dams (Liu et al., 2015). By the end of 2007, there were 47 check-dams, including 21 large and 26 medium and small-sized dams (Ordos Soil Conservation Service, 2010a). By 2008, two large and 11 medium and small-sized checkdams were added (Ordos Soil Conservation Service, 2010b). Ran et al. (2004) suggested that check-dams are the most efficient means to retain sediment. Building check-dams can cut off the strong coupling between hyperconcentrated flows and gravitational erosion through raising the base-level and reducing the slopes of gullies, thereby causing hyperconcentrated flows to lose energy and leading to sediment deposition (Xu, 1999).

\subsection{The relation between intensive rainfall and sediment yield}

Soil erosion from a watershed depends on many factors such as rainfall intensity and duration, runoff, soil erodibility, topography and landform, and vegetation coverage. Among the major factors controlling soil erosion, rainfall erosivity is of paramount importance because several very intense rainfall events are responsible for the largest proportion of soil erosion (Angulo-Martínez and Beguería, 2009). Zhou and Wang (1992) demonstrated that most of the soil erosion on the Loess Plateau was caused by several rainstorms and that more than $90 \%$ of the rainfall did not generate surface runoff. The soil loss caused by a few rainstorms accounted for $60 \%-90 \%$ of the total soil loss on the Loess Plateau. Here, to investigate the relationship between the rainstorms and the probability of occurrence of hyperconcentrated flows, we calculated the frequency of hyperconcentrated flows for different daily rainfall intensity. The statistical results (Fig. 11) indicated that hyperconcentrated flows did not occur when daily rainfall was less than $12 \mathrm{~mm}$. Such small rainfalls do not have the capacity to cause soil erosion, consistent with the suggestion by Zhang et al. (2002). For daily rainfall greater than $12 \mathrm{~mm}$, the frequency of hyperconcentrated flows increased with rainfall intensity (Fig. 12). In 1964-1990, only half of the daily rainfall greater than $40 \mathrm{~mm}$ led to hyperconcentrated flows, and all of the daily rainfall greater than $80 \mathrm{~mm}$ gave rise to hyperconcentrated flows. In 2006-2013, the frequency of hyperconcentrated flows for the same intensity of rainstorms was noticeably lower than that in 1964-1990. Furthermore, we compared the average sediment concentration and sediment yield for different daily rainfalls $(0-12,12-20,20-30,30-40$, $40-50,50-60,>70 \mathrm{~mm}$ ) in 1964-1990 with those in 2006-2013 (Fig. 13). The plot demonstrates that the average sediment concentration and sediment yield in 2006-2013 were much smaller than those in 1964-1990. The reduced percentages of the average sediment concentration were $90.6 \%, 97.4 \%, 96.9 \%, 90.1 \%, 95.0 \%, 39.9 \%, 95.9 \%$ and $77.0 \%$ for daily rainfalls of $0-12,12-20,20-30,30-40,40-50,50-60$ and $>70 \mathrm{~mm}$, respectively. For the average sediment yield, the reduced percentages were 59.1\%, 99.5\%, 99.5\%, 96.2\%, 98.4\%, 36.9\%, 99.7\% and

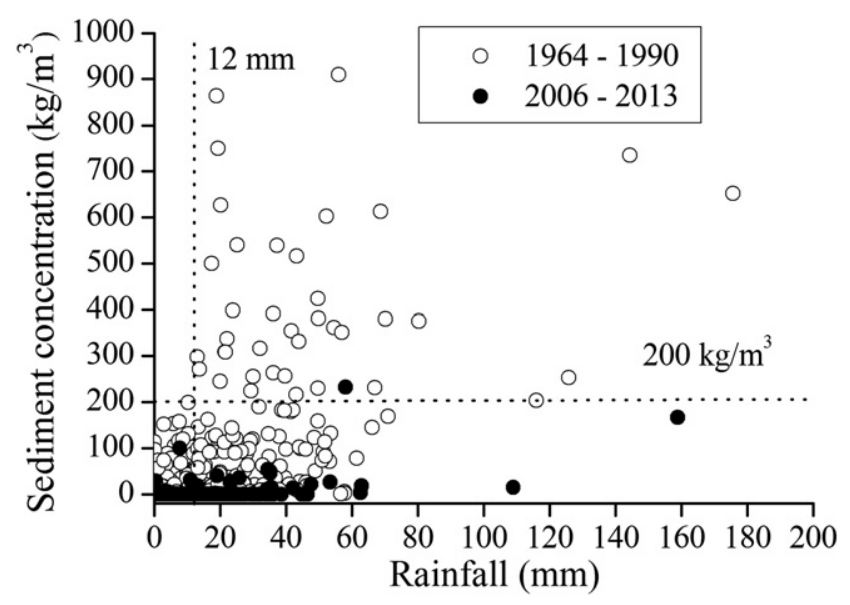

Fig. 11. The relationship between daily rainfall and sediment concentration.

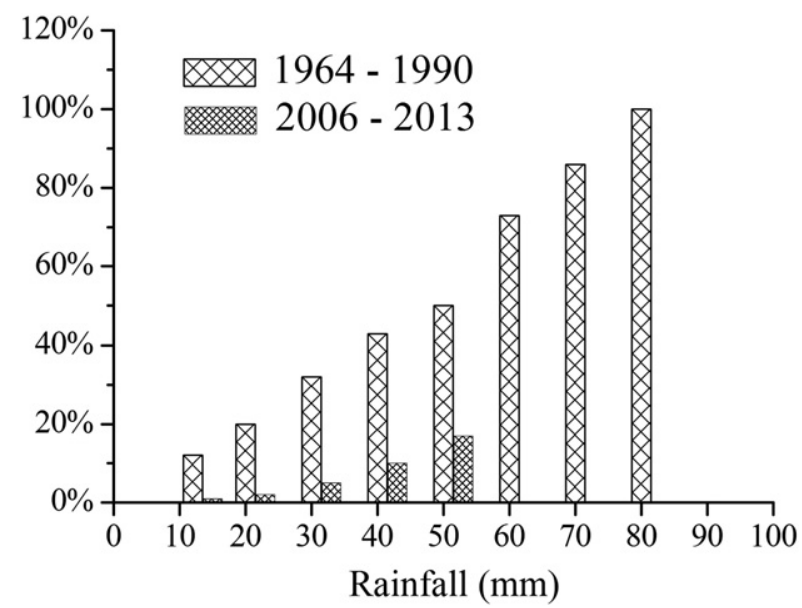

Fig. 12. The frequency distribution of hyperconcentrated flows with different daily rainfalls.

91.7\%. This phenomenon should be the consequence of human activity. As mentioned above, many soil and water conservation measures have been implemented in the basin since 1999. These measures have altered the local micro-topography landform and changed the relationships between rainfall, runoff and soil erosion. Therefore, under the same rainfall conditions, the sediment concentration in 2006-2013 was significantly lower than that in 1964-1990.

\section{Conclusions}

In this study, we analyzed the variation of sediment yield in the Xiliugou basin based on the hydrological and sediment records in the period 1960-2013 and identified the factors that affected the sediment yield in the basin. The annual sediment yield in this basin showed a significant decreasing trend, whereas no significant trend was detected in the annual precipitation. Based on an abrupt change in 1998 that was identified in the sediment series, the years from 1960 to 2013 were divided into two periods: 1960-1998 and 1999-2013. In comparison with the period 1960-1998, the sediment yield from 1999 to 2013 was reduced by $82.1 \%$.

Hyperconcentrated floods were common and transferred most of the sediment yield in the Xiliugou basin. The hyperconcentrated floods occurred in $87.1 \%$ of the years and transferred $84.7 \%$ of the total sediment load during the period 1960-1990. Since the 2000s, the number of hyperconcentrated floods decreased considerably with the application of soil and water conservation, and only one hyperconcentrated flood was recorded in the period 2006-2013.

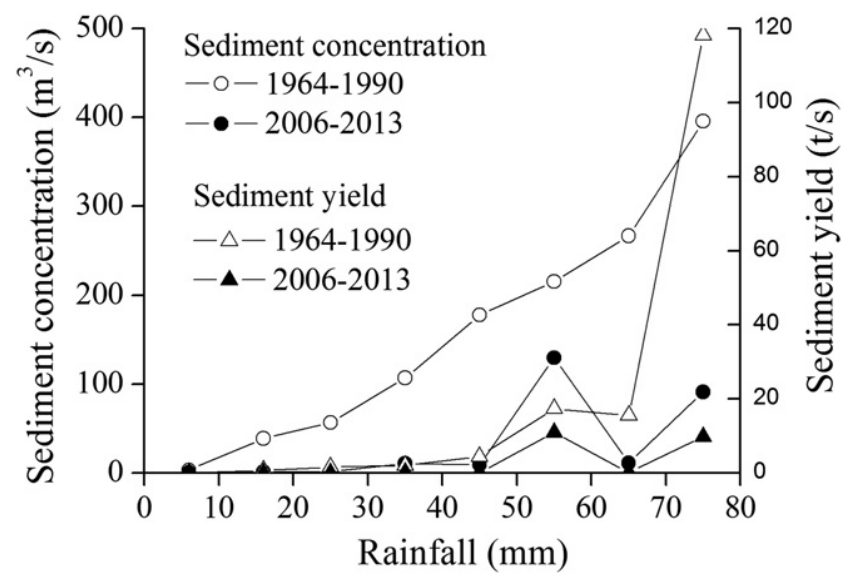

Fig. 13. The average sediment concentration and sediment yield with different daily rainfalls. 
Hyperconcentrated flows may cause intensive erosion in gullies, and gully erosion could be the main sediment source in the Xiliugou basin. The percentages of gully erosion and slope erosion from 1964 to 1990 were estimated to be $76.1 \%$ and $23.9 \%$, respectively. It is worth to mention that the processes of the hyperconcentrated flow generation are not observed in the Xiliugou basin and the results of the RUSLE model have not been validated owing to the lack of the measured slope erosion data. Thus, the results of this study may be regarded as preliminary and heuristic ones and need to be checked in the future.

Daily rainfalls greater than $12 \mathrm{~mm}$ can cause hyperconcentrated flows, and the frequency of hyperconcentrated floods increases with the rainfall intensity. Compared with the period 1964-1990, the frequency of hyperconcentrated flows, the annual sediment concentration and sediment yield for the same intensity of rainstorms were noticeably lower in 2006-2013 owing to vegetation recovery and check-dam building. The implementation of water and soil conservation measures and the reduced frequency of hyperconcentrated floods played an important role in the reduction of the sediment yield in the period 2006-2013.

\section{Acknowledgments}

This work was supported by the National Natural Science Foundation of China (Grant No. 41371036) and the National Major Basic Research Program of China (Grant No. 2011CB403305). Many thanks go to Dr. Owen, and two anonymous reviewers for their constructive comments.

\section{References}

Ahn, K.H., Merwade, V., 2014. Quantifying the relative impact of climate and human activities on streamflow. J. Hydrol. 515, 257-266.

Angulo-Martínez, M., Beguería, S., 2009. Estimating rainfall erosivity from daily precipitation records: a comparison among methods using data from the Ebro Basin (NE Spain). J. Hydrol. 379, 111-121

Cai, Q.G., Lu, Z.X., WG, 1996. Process-based soil erosion and sediment yield model in small basin in the hilly loess region. Acta Geograph. Sin. 51, 108-117 (in Chinese with English abstract)

Cai, C.F., Ding, S.W., Shi, Z.H., Huang, L., Zhang, G.Y., 2000. Study of applying USLE and geographical information system IDRISI to predict soil erosion in small watershed. J. Soil Water Conserv. 14, 19-24 (in Chinese with English abstract).

De Vente, J., Poesen, J., Verstraeten, G., 2005. The application of semi-quantitative methods and reservoir sedimentation rates for the prediction of basin sediment yield in Spain. J. Hydrol. 305, 63-86.

Du, H., Xue, X., Wang, T., 2014. Estimation of saltation emission in the Kubuqi Desert, North China. Sci. Total Environ. 479-480, 77-92.

Fan, X., Shi, C., Zhou, Y., Shao, W., 2012. Sediment rating curves in the Ningxia-Inner Mongolia reaches of the upper Yellow River and their implications. Quat. Int. 282, $152-162$

Gao, P., Mu, X.M., Wang, F., Li, R., 2011. Changes in streamflow and sediment discharge and the response to human activities in the middle reaches of the Yellow River. Hydrol. Earth Syst. Sci. 15, 1-10.

Gebremicael, T.G., Mohamed, Y.A., Betrie, G.D., van der Zaag, P., Teferi, E., 2013. Trend analysis of runoff and sediment fluxes in the Upper Blue Nile basin: a combined analysis of statistical tests, physically-based models and landuse maps. J. Hydrol. 482, $57-68$.

Kendall, M., 1975. Rank Correlation Measures. Charles Griffin, London.

Krause, A.K., Franks, S.W., Kalma, J.D., Loughran, R.J., Rowan, J.S., 2003. Multi-parameter fingerprinting of sediment deposition in a small gullied catchment in SE Australia. Catena 53, 327-348

Liu, B.Y., Nearing, M.A., Rise, L.M., 1994. Slope gradient effects on soil loss for steep slopes. Trans. ASAE 37, 1835-1840.

Liu, X.Y., Hou, S.Z., Chang, W., 2009. Cause of main channel shrinkage occurred to the Inner Mongolia reaches of Yellow River. Shui Li Xue Bao 40, 1048-1054 (in Chinese with English abstract).

Liu, C., Sui, J., He, Y., Hirshfield, F., 2013. Changes in runoff and sediment load from major Chinese rivers to the Pacific Ocean over the period 1955-2010. Int. J. Sediment Res. $28,486-495$.

Liu, T., Huang, H.Q., Shao, M.A., Liu, G.H., Yang, Y.Z., 2015. Impacts of climate change and human activities on process of water and sediment load along Yellow River in Erdos. J. Soil Water Conserv. 29, 17-22 (in Chinese with English abstract).

Xin, Z.B., Ran, L.S., Lu, X.X., 2012. Soil erosion control and sediment load reduction in the Loess Plateau : policy perspectives. Int. J. Water Resour. Dev. 28 (2), 325-341.

Lu, X.X., Ran, L.S., Liu, S., Jiang, T., Zhang, S.R., Wang, J.J., 2013. Sediment loads response to climate change: a preliminary study of eight large Chinese rivers. Int. J. Sediment Res. 28, 1-14.
Ma, Y.F., Yan, P., Li, S.Q., 2013. Dynamic process of aeolian-fluvial interaction erosion in the middle reaches of Baerdong River in ten-watershed, Inner Mongolia of China. J. Desert Res. 33, 990-999 (in Chinese with English abstract)

Mann, H.B., 1945. Nonparametric tests against trend. Econometrica 13, 245-259.

McCool, D.K., Foster, G.R., Weesies, G.A., 1997. Slope-length and steepness factors (LS). Predicting soil erosion by water: a guide to conservation planning with the Revised Universal Soil Loss Equation (RUSLE). USDA Agriculture Handbook.

Miao, C.Y., Ni, J.R., Borthwick, A.G.L., 2010. Recent changes of water discharge and sediment load in the Yellow River basin, China. Prog. Phys. Geogr. 34, 541-561.

Mu, X., Zhang, X., Shao, H., Gao, P., Wang, F., Jiao, J., Zhu, J., 2012. Dynamic changes of sediment discharge and the influencing factors in the Yellow River, China, for the recent 90 years. Clean-Soil Air Water 40, 303-309.

Ordos Soil Conservation Service, 2010a. The Engineering Situation of Check-dams in Ordos. (http://www.ordossb.gov.cn/zdgc/201004/t20100421_181730.html).

Ordos Soil Conservation Service, 2010b. The Summary Table of Check-dams Safety Inspection in Ordos. (http://www.ordossb.gov.cn/zdgc/201004/P020100421617480296014.xls).

Pelletier, J.D., 2012. A spatially distributed model for the long-term suspended sediment discharge and delivery ratio of drainage basins. J. Geophys. Res. 117, 1-15.

Pettitt, A.N., 1979. A non-parametric approach to the change-point problem. Appl. Stat. 126-135.

Poesen, J., Nachtergaele, J., Verstraeten, G., Valentin, C., 2003. Gully erosion and environmental change: importance and research needs. Catena 50, 91-133.

Qin, Y., Zhang, X.F., Wang, L.F., Yan, H., Han, H.J., 2011. Scour and silting evolution and its influencing factors in Inner Mongolia reach. Acta Geograph. Sin. 66, 324-330 (in Chinese with English abstract).

Ran, D.C., Luo, Q.H., Liu, B., Wang, H., 2004. Effect of soil-retaining dams on flood and sediment reduction in middle reaches of Yellow River. Shui Li Xue Bao 35, 7-13 (in Chinese with English abstract).

Renard, K.G., Foster, G.R., Weesies, G.A., McCool, D.K., Poder, D.C. 1997. Predicting soil erosion by water: a guide to conservation planning with the Revised Universal Soil Loss Equation (RUSLE). USDA Agriculture Handbook, Washington.

Rougé, C., Ge, Y., Cai, X., 2013. Detecting gradual and abrupt changes in hydrological records. Adv. Water Resour. 53, 33-44.

Shi, C., Zhou, Y., Fan, X., Shao, W., 2013. A study on the annual runoff change and its relationship with water and soil conservation practices and climate change in the middle Yellow River basin. Catena 100, 31-41.

Sun, W., Shao, Q., Liu, J., Zhai, J., 2014. Assessing the effects of land use and topography on soil erosion on the Loess Plateau in China. Catena 121, 151-163.

Syvitski, J.P.M., Milliman, J.D., 2007. Geology, geography, and humans battle for dominance over the delivery of fluvial sediment to the coastal ocean. J. Geol. 115, 1-19.

Syvitski, J.P.M., Vörösmarty, C.J., Kettner, A.J., Green, P., 2005. Impact of humans on the flux of terrestrial sediment to the global coastal ocean. Science 308, 376-380.

Tang, K.L., 1991. Soil Erosion on the Loess Plateau: Its Regional Distribution and Control. China Science and Technology Press, Beijing (in Chinese).

Valentin, C., Poesen, J., Li, Y., 2005. Gully erosion: impacts, factors and control. Catena 63, $132-153$.

Vanmaercke, M., Poesen, J., Broeckx, J., Nyssen, J., 2014. Sediment yield in Africa. Earth-Sci. Rev. 136, 350-368.

Walling, D.E., 2006. Human impact on land-ocean sediment transfer by the world's rivers. Geomorphology 79, 192-216.

Walling, D.E., 2009. The Impact of Global Change on Erosion and Sediment Transport by Rivers: Current Progress and Future Challenges.

Walling, D.E., Fang, D., 2003. Recent trends in the suspended sediment loads of the world's rivers. Glob. Planet. Change 39, 111-126.

Wan, Z., Shen, S., 1978. Hyperconcentrated flows in relation with sedimentation of the Yellow River and its tributaries. In: Research Group of Yellow River Sedimentation (Ed.), Selected Research Reports on Sedimentation of the Yellow River (in Chinese).

Wang, P., Hou, S.Z., Zhang, Y.F., Wu, B.S., 2013. Scouring and silting characteristics of hyperconcentrated floods of ten tributaries of upper Yellow River. J. Sediment. Res. 67-73 (in Chinese with English abstract).

Wasson, R.J., Caitcheon, G., Murray, A.S., McCulloch, M., Quade, J., 2002. Sourcing sediment using multiple tracers in the catchment of Lake Argyle, Northwestern Australia. Environ. Manag. 29, 634-646.

Wei, W. Chen, L. Zhang, H., Chen, J. 2015. Effect of rainfall variation and landscape change on runoff and sediment yield from a loess hilly catchment in China. Environ. Earth Sci. 73, 1005-1016.

Williams, J.R., Jones, C.A., Dyke, P.T., 1984. A modeling approach to determining the relationship between erosion and soil productivity. Trans. ASAE 27, 129-144.

Wu, C.S., Yang, S.L., Lei, Y.P., 2012. Quantifying the anthropogenic and climatic impacts on water discharge and sediment load in the Pearl River (Zhujiang), China (1954-2009). J. Hydrol. 452-453, 190-204.

Xiao, L., Yang, X., Chen, S., Cai, H., 2015. An assessment of erosivity distribution and its influence on the effectiveness of land use conversion for reducing soil erosion in Jiangxi, China. Catena 125, 50-60.

Xin, Z.B., Yu, B.F., Han, Y.G., 2015. Spatiotemporal variations in annual sediment yield from the middle Yellow River, China, 1950-2010. J. Hydrol. Eng. 1-15.

Xu, J.X., 1999. Erosion caused by hyperconcentrated flow on the Loess Plateau of China. Catena 36, 1-19.

Xu, J.X., 2004. Hyperconcentrated flows in the slope-channel systems in gullied hilly areas on the Loess Plateau, China. Geogr. Ann. A 86 (4), 349-366.

$\mathrm{Xu}, \mathrm{J} . \mathrm{X} ., 2$ 2013. Erosion and sediment yield of 10 small tributaries joining Inner-Mongolia reach of upper Yellow River in relation with coupled wind-water processes and hyperconcentrated flows. J. Sediment. Res. 28-37 (in Chinese with English abstract).

Xu, J.X., 2014. Temporal and spatial variations in erosion and sediment yield and the cause in the ten small tributaries to the Inner Mongolia reach of the Yellow River. J. Desert Res. 34, 1-9 (in Chinese with English abstract). 
Yang, Y., 2012. The Study on the Relationship Between Land Use/Cover and Soil Erosion in Duolun County of Inner Mongolia. Inner Mongolia Agricultural University (in Chinese with English abstract).

Zhang, W.B., Xie, Y., Liu, B., 2002. Rainfall erosivity estimation using daily rainfall amounts. Sci. Geogr. Sin. 22, 705-711 (in Chinese with English abstract)

Zhang, Q., Li, J., Chen, Y.D., Chen, X., 2011. Observed changes of temperature extremes during 1960-2005 in China: natural or human-induced variations? Theor. Appl. Climatol. 106, 417-431.
Zhang, Y., Wang, P., Wu, B., Hou, S., 2015. An experimental study of fluvial processes at asymmetrical river confluences with hyperconcentrated tributary flows. Geomorphology 230, 26-36.

Zhao, G., Mu, X., Strehmel, A., Tian, P., 2014. Temporal variation of streamflow, sediment load and their relationship in the Yellow River Basin, China. PLoS One 9, e91048.

Zhou, P.H., Wang, Z.L., 1992. A study on rainstorm causing soil erosion in the Loess Plateau. J. Soil Water Conserv. 6, 1-5 (in Chinese with English abstract). 